\title{
Combined Production of Biofuels from Locally Grown Microalgae
}

\author{
N. Adam ${ }^{a, *}$, A. Shanableh ${ }^{a, b}$ \\ ${ }^{a}$ Department of Civil and Environmental Engineering University of Sharjah, Sharjah, United Arab Emirates \\ ${ }^{b}$ Research Institute of Sciences and Engineering, University of Sharjah, PO Box 2727, Sharjah, United Arab Emirates
}

\begin{abstract}
The purpose of this study was to assess the potential of combining the production of three types of biofuels (i.e., biodiesel, bioethanol, and biogas) from Nannochloropsis sp. microalgae. Cellulase enzyme, produced from Trichoderma viride fungi was used to convert algal hydrocarbons into sugars for bioethanol production and to improve lipids extraction for biodiesel production. The procedure for producing the three biofuels consisted of initially mixing predetermined quantities of cellulose with the algae to hydrolyze the complex hydrocarbons and produce sugars, followed by oil extraction from the hydrolyzed algae, and finally producing biogas through co-digesting the hydrolyzed and oil-extracted algae residual with wastewater treatment sludge. Without enzyme, the total sugar yield following hydrolysis for 6 hours with distilled water at $37^{\circ} \mathrm{C}$ and $\mathrm{pH} 5$ reached $38 \mathrm{mg} / \mathrm{g}$ algae. Using the enzyme, total sugar production increased in the range of 42 $\mathrm{mg} / \mathrm{g}$ algae to $74 \mathrm{mg} / \mathrm{g}$ algae with increasing enzyme use. Similarly, the reducing sugar production increased from 36 $\mathrm{mg} / \mathrm{g}$ algae without enzyme to $60 \mathrm{mg} / \mathrm{g}$ algae with increasing enzyme dose. Following hydrolysis, the lipids yield reached $59 \%$ of the extracted algae weight, which represents almost all of the lipids in the algae. The residual algae mixed with sludge generated significant amounts of biogas in excess of the quantities generated by sludge alone. The results demonstrated the technical feasibility of producing three biofuels from algae; however the economic aspects of the process require significant further careful consideration.
\end{abstract}

Keywords: Biofuels, Biogas, Biodiesel, Ethanol, Enzymatic Hydrolysis, Sugars, Oil, Renewable Energy, Microalgae.

\section{Introduction}

Biofuels are fuels generated from living organisms, and include: biomass; biodiesel; bioethanol; and biogas. Biofuels are promising alternatives to fossil fuels because they are carbon neutral and can reduce dependence on fossil fuels [1]. A variety of feedstocks can be used to produce biofuels, but feasible production requires abundant and renewable sources of biomass. The interest in utilizing algae as an attractive feedstock to produce biofuels has increased worldwide [2,3]. Microalgae in particular can convert carbon dioxide into high value organic products [4,5], including lipids, hydrocarbons, and proteins. Moreover, algae do not require fresh water or agricultural land, and do not compete with food sources. Furthermore, $\mathrm{CO}_{2}$ emissions from fossil fuel burning facilities can be captured by algae and used to grow algae through photosynthesis [6].
Microalgae cell walls contain low content of hemicellulose and almost no lignin compared to lignocellulosic biomass, which reduce the need for pretreatment and improves extraction of useful resources from their cells [7]. A variety of pre-treatment methods are available to enhance extraction of algal organic resources [8-11], including pretreatment using enzymes [12]. The overall objective of this study was to explore the possibility of producing three types of biofuels from locally grown microalgae. The three biofuels are: bioethanol; biodiesel; and biomethane. In the study, bioethanol is indicated by production of sugars; biodiesel is indicated by production of oil, and biomethane is indicated by anaerobic production of biogas.

\section{Materials and Methods}

The type of microalgae used in this study is Nannochloropsis sp., which is grown locally and is known to contain large amounts of lipids (approximately $60 \%$ lipids, $10 \%$ proteins, and 30\% carbohydrates [13]). Nannochloropsis sp., a unicellular marine green algae, is locally grown to feed fish in fish farms. Microalgae samples were prepared for biofuels production

${ }^{*}$ Corresponding author. Tel.: +971 065050439

Fax: +971 06 5585173; E-mail: nadam@sharjah.ac.ae

(C) 2016 International Association for Sharing Knowledge and Sustainability

DOI: 10.5383/ijtee.13.01.002 
through washing, drying and grinding to a powder. The algae were then subjected to treatment using cellulase enzyme produced by Trichoderma viride fungi with activity of 3-10 units/mg to hydrolyze hydrocarbons and produce sugars.

Enzymatic hydrolysis was carried out for 6 hours at $\mathrm{pH} 5$ and $37^{\circ} \mathrm{C}$ in $500 \mathrm{~mL}$ glass laboratory beaker filled with $5 \mathrm{~g}$ algae mixed with $250 \mathrm{~mL}$ sodium acetate buffer. The flasks were mixed in a water bath incubator shaker (Clifton NE5-28D, UK) at a speed of $300 \mathrm{rpm}$. The enzyme dosages added to the samples (designated S1 to S9) were in the range of $0 \mathrm{mg}$ to $250 \mathrm{mg}$. Following hydrolysis for 6 hours, the enzymatic reaction was stopped by heating the contents of all flasks to $95^{\circ} \mathrm{C}$. It should be noted that the buffer was brought to a temperature of $37^{\circ} \mathrm{C}$ in the incubator before adding the enzyme.

Two control samples were used with each hydrolysis batch; one (designated B1) involved algae mixed with distilled water at $\mathrm{pH}$ 5 without using sodium acetate buffer and without adding enzyme; and another (designated B2) involved algae mixed with sodium acetate buffer at $\mathrm{pH} 5$ but without adding enzyme. The enzyme quantities used for hydrolysis and samples designations are summarized in Table 1.

Table 1. Enzyme quantities used for hydrolysis and samples designations

\begin{tabular}{ccccccccccc}
\hline B1 & B2 & S1 & S2 & S3 & S4 & S5 & S6 & S7 & S8 & S9 \\
\hline 0 & 0 & 1 & 5 & 10 & 20 & 40 & 80 & 150 & 200 & 250
\end{tabular}

The total sugars content was determined colormetrically, based on the absorbance at $490 \mathrm{~nm}$, using the Total Phenol-Sulfuric Acid Method [14]. Reducing sugar was also determined colormetrically, based on the absorbance at $540 \mathrm{~nm}$, using the DNSA method proposed by Miller [15]. Supernatant samples were prepared for sugar measurement through centrifuging the hydrolyzed algae samples at $10,000 \mathrm{rpm}$ for 10 minutes to separate the solids from the liquid, then diluting the samples as needed. Glucose standards were used to determine the concentration of sugars in the samples.

Blank and enzyme-pretreated algae were subjected to morphological analysis using scanning electron microscopy (SEM) to examine enzyme effect. Dried algae samples were mounted on metal stubs by double tape and the surface was coated with copper to avoid charging. The samples were observed with SEM and images were taken by VEGA 3 TESCAN camera.

Lipid extraction was performed on $6 \mathrm{~g}$ dried algae samples that remained after enzymatic hydrolysis. Extraction was achieved in a soxhlet extractor apparatus shown in Fig. 1 (B-811 LSV, Switzerland) using a mixture of methanol, chloroform, and water with volumetric mixture ratios of (2:1:0.8). The extraction apparatus automatically rinses and dries the oil after extraction. The extracted oil was collected and its weight measured.

Following oil extraction, the residual algae was soaked in distilled water for 12 hours then oven dried. Residual algae samples $(0.07 \mathrm{~g})$ were mixed with $30 \mathrm{~mL}$ sludge samples containing $2 \%$ total solids (TS) in $50 \mathrm{~mL}$ capped serum bottles and incubated at $37^{\circ} \mathrm{C}$ to generate biogas through anaerobic digestion. The $\mathrm{pH}$ of the algae-sludge mixtures were adjusted, if necessary, to approximately 7.25. Control samples containing sludge alone, sludge with raw algae, and sludge with oil extracted but not enzyme-hydrolyzed algae were also used. Biogas production was measured periodically through inserting a hypodermic needle into the rubber stopper of the serum bottle to displace water in a U-shaped graduated manometer filled with acidified water. All experiments and analytical methods were conducted in duplicate and triplicates, and the results are presented as means

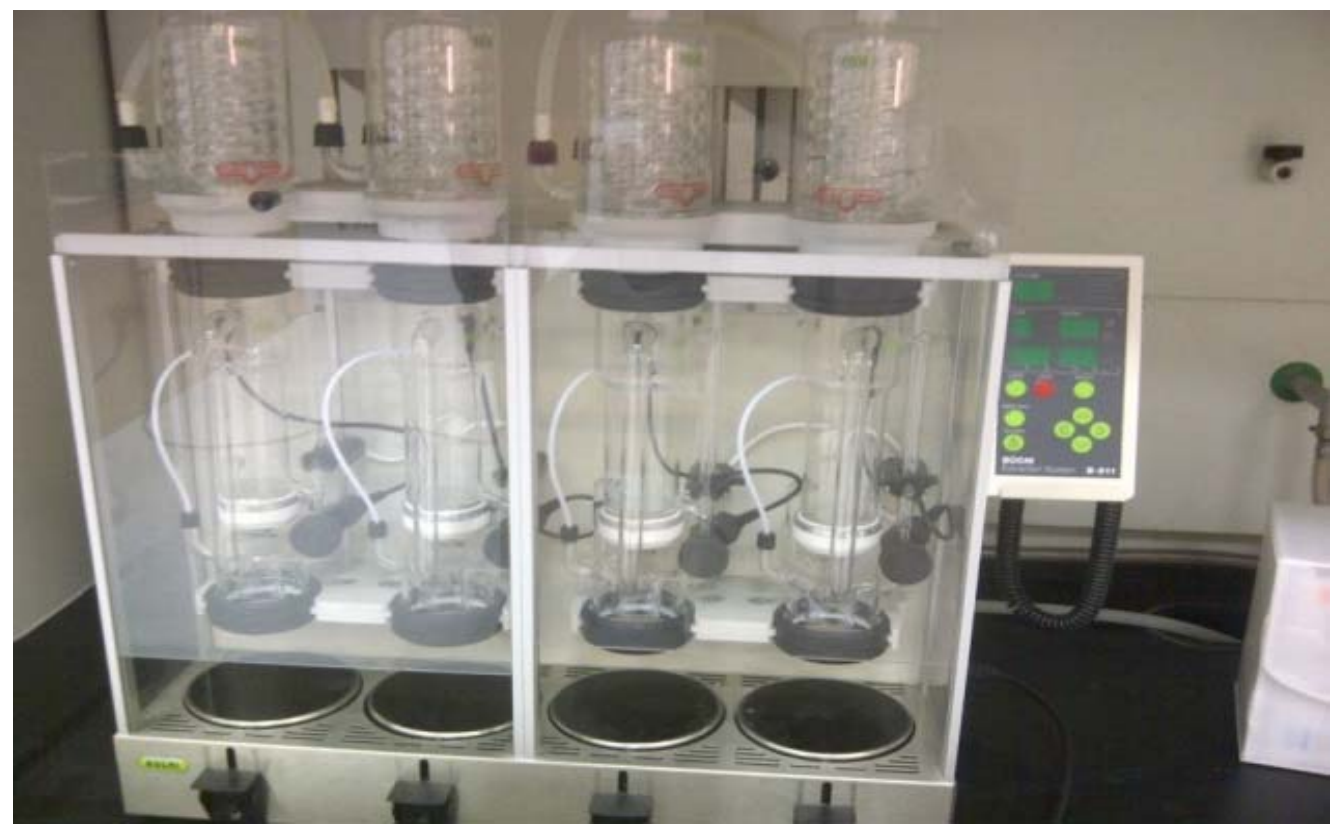

Fig. 1. Automatic oil extraction apparatus 


\section{Results and Discussion}

Hydrolysis of algae hydrocarbons in distilled water without the use of enzyme at $37^{\circ} \mathrm{C}$ and $\mathrm{pH} 5$ resulted in the production of $37.4 \mathrm{mg}$ total sugar per gram algae and $35.9 \mathrm{mg}$ reducing sugar per g algae (Figs. 2 and 3). Similarly, hydrolysis using the acetate buffer, but without the use of enzyme, resulted in 48.6 $\mathrm{mg}$ total sugar per gram algae and $42.1 \mathrm{mg}$ reducing sugar per $\mathrm{g}$ algae. Hydrolysis without the use of enzyme suggests the presence of readily hydrolysable hydrocarbons. Using the enzyme, the data show that total sugar yield following hydrolysis increased in the range of $42 \mathrm{mg} / \mathrm{g}$ algae to $74 \mathrm{mg} / \mathrm{g}$ algae. Similarly, the reducing sugar increased in the range of 36 $\mathrm{mg} / \mathrm{g}$ algae to $60 \mathrm{mg} / \mathrm{g}$ algae with increasing enzyme use.

The quantity of hydrolyzed hydrocarbon, which reached a maximum of $7.4 \%$ by weight, is moderate to low. However, the chosen microalgae type is typically used for oil production as it contains significant quantities of lipids. Nevertheless, enzymatic pretreatment increased sugar production from algae significantly.

The SEM pictures in Fig. 4 provide a direct evidence of enzyme effect on algae, which helps explain the increase in total and reducing sugar production as the enzyme dose increased. Analysis of the SEM images reveals ultra-structural changes in algae. The least treated blank sample (B1) shows the most intact cell structure with no significant pitting or cell disruption/lysis.
The B1 sample surface looks even, smooth and continuous. The other blank sample (B2), which was hydrolyzed using the acetate buffer but without enzyme, shows partial cell disruption. On the other hand, the use of enzyme in samples S1 to S5 resulted in visible damage to the cell structure.

The lipid extraction results following algae hydrolysis were variable, as shown in Fig. 5. The variability of the results was initially surprising but it was soon realized that the four heating elements of the lipids extraction apparatus shown in Fig. 1 operated at different temperatures. Nevertheless, the extracted lipids ranged between $41 \%$ to $58.8 \%$ of the weight of the algae in the samples treated with enzyme compared to the blank samples (31\% for B1 and 39.5\% for B2). The results clearly demonstrate that significant quantities of lipids can be extracted from the algae following enzymatic hydrolysis to produce sugars.

The results in Fig. 6 show that compared to sludge alone, biogas production generally increased as a result of addition of algae to the wastewater sludge. As expected, the highest biogas quantity was produced from the samples containing sludge and blank algae (B1) then from sludge and blank algae (B2) because the blank B1 and B2 samples contained the highest quantities of biodegradable organic matter as they were not subjected to oil extraction or enzymatic treatment. In comparison, the samples containing sludge alone produced the least amount of biogas. For the other samples, biogas production was consistent with the results of oil extraction and hydrolysis.

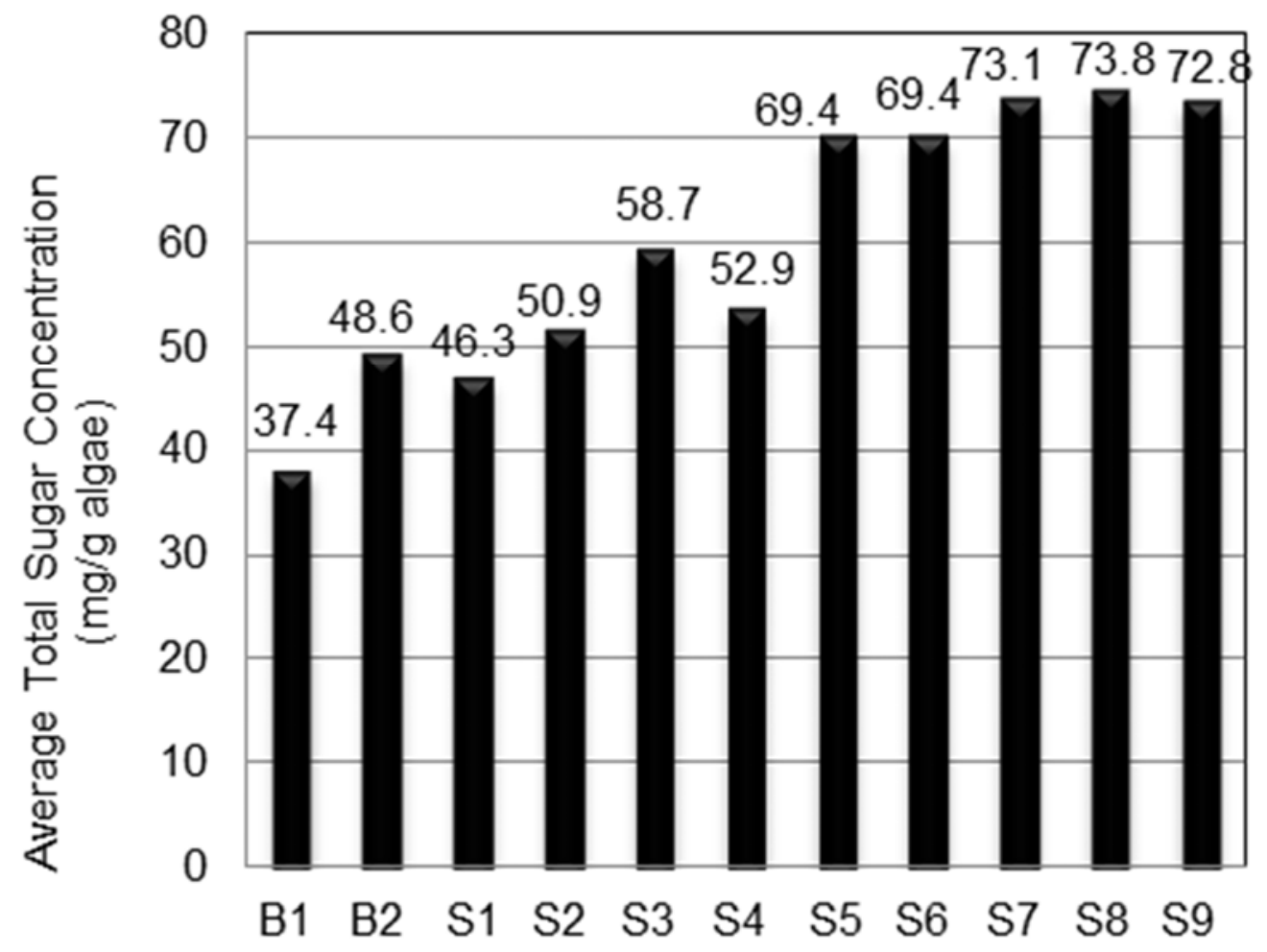

\section{Sample ID}

Fig. 2. Effect of enzyme quantity on total sugar production 


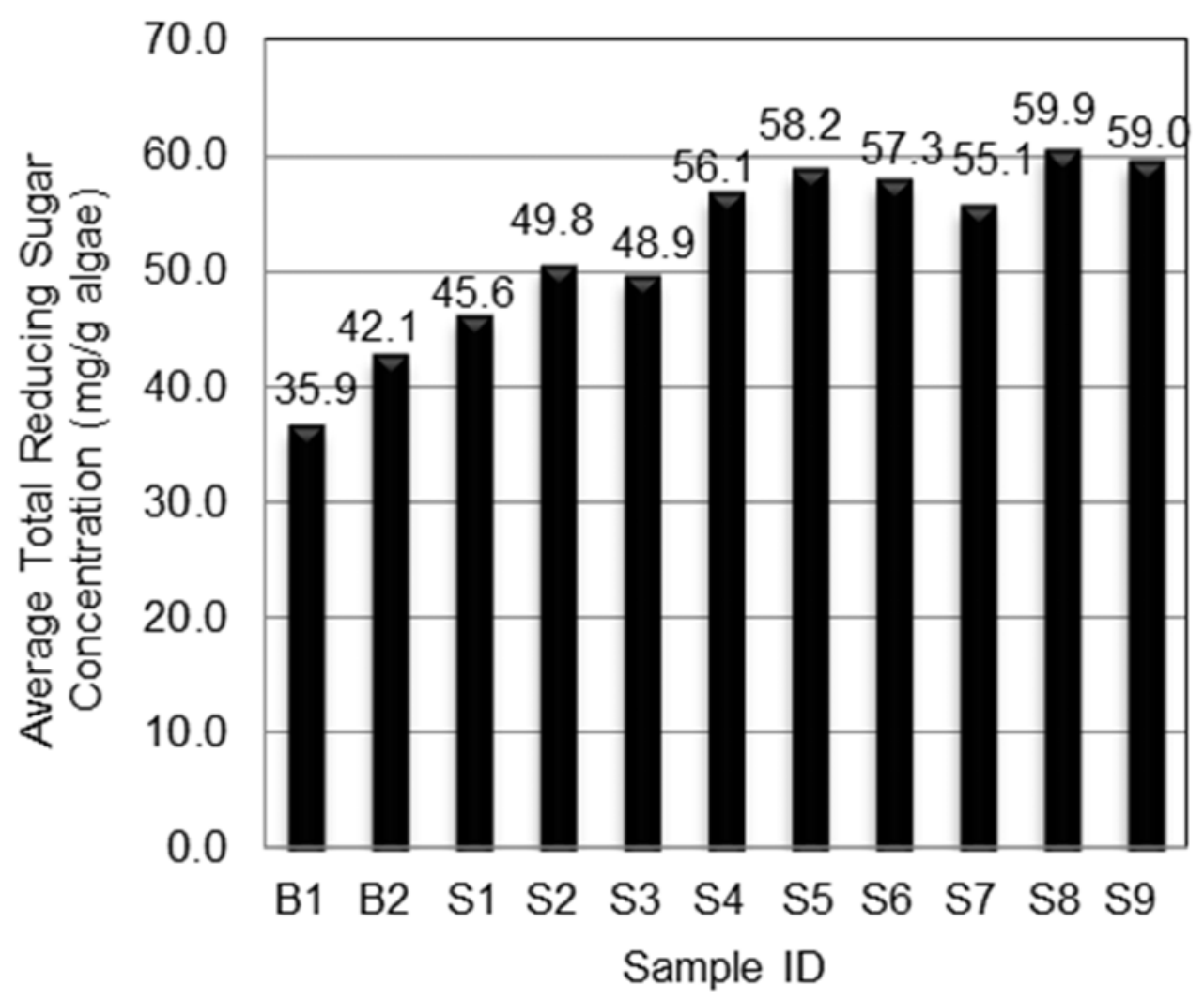

Fig. 3. Effect of enzyme quantity on reducing sugar production
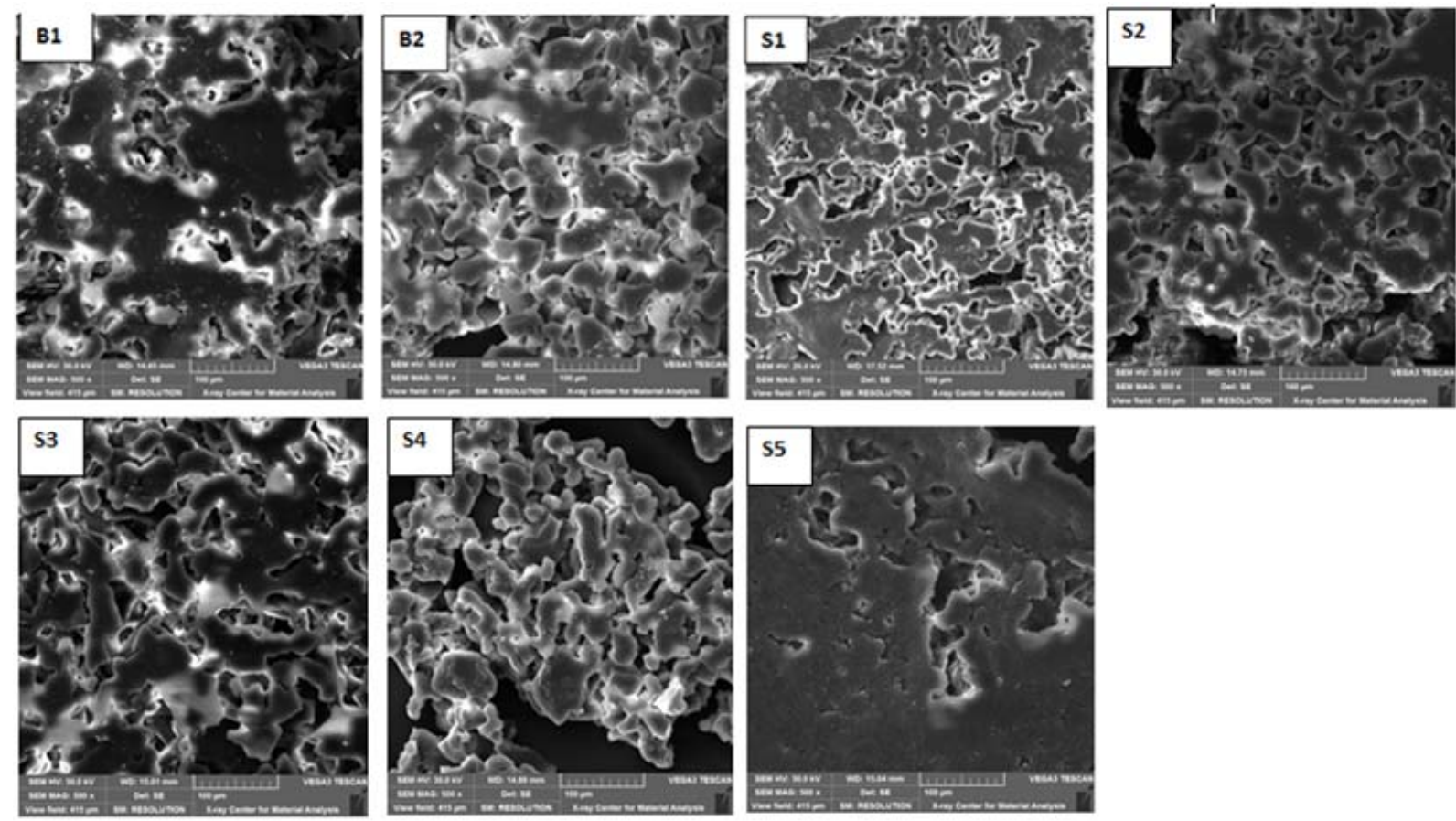

Fig. 4. SEM Images of morphological analysis following algae hydrolysis 
Adam and Shanableh / Int. J. of Thermal \& Environmental Engineering, 13 (2016) 7-12

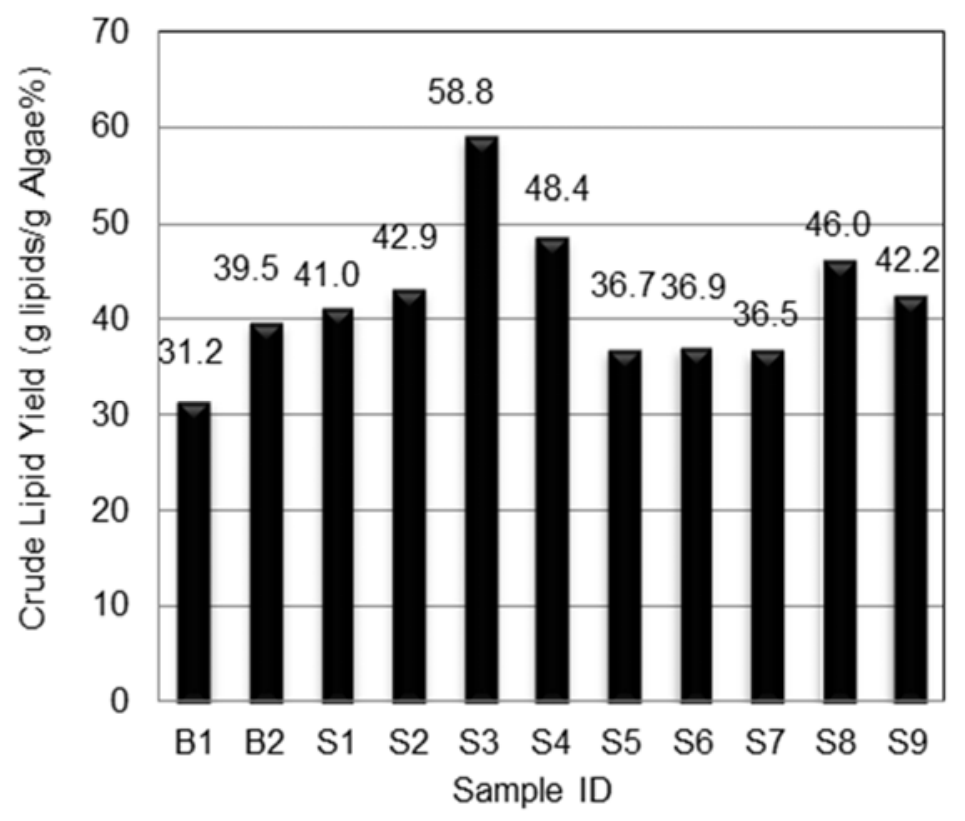

Fig. 5. Lipids extraction results

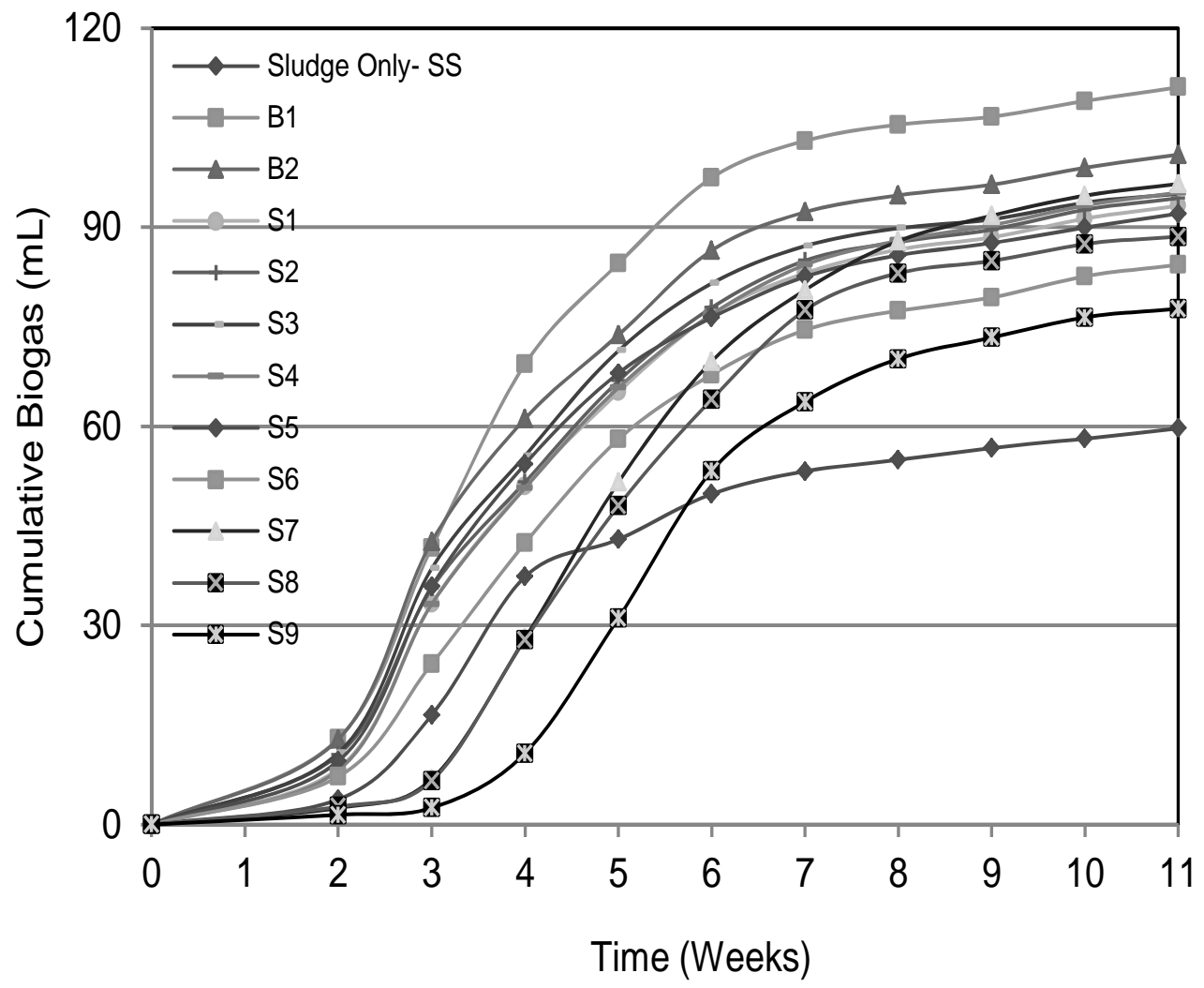

Fig. 6. Biogas production during 11 weeks of anaerobic incubation of samples 


\section{Conclusions}

The results of this study confirmed the possibility of combining the production of three biofuels from Nannochloropsis sp. algae through production of sugars, oil and biogas. Hydrolysis of cell hydrocarbons using cellulase enzyme resulted in maximum total sugar production of $74 \mathrm{mg} / \mathrm{g}$ algae and maximum reducing sugar production of $60 \mathrm{mg} / \mathrm{g}$ algae. Following hydrolysis, lipids extraction generated $59 \% \mathrm{~g}$ oil/g algae, which represents almost all of the lipids in the algae. Furthermore, the residual, hydrolyzed and oil-extracted algae, mixed with wastewater sludge, generated significant amounts of biogas in excess of the quantities generated by sludge alone. As this study is exploratory, additional studies are required to confirm the results and to optimize the production of the three biofuels from various species of algae.

\section{References}

[1] Y. Chisti, Biodiesel from microalgae. Biotechnology Advances 2007; 3: 294-306, DOI: 10.1016/j.biotechadv.2007.02.001

[2] G.D.Iyovo, G. Du, and J. Chen. Sustainable Bioenergy Bioprocessing: Biomethane Production, Digestate as Biofertilizer and as Supplemental Feed in Algae Cultivation to Promote Algae Biofuel Commercialization. J Microbial Biochem Technol 2010; 2: 100-106, DOI:10.4172/1948-5948.1000032

[3] A. Demirbas, 'Importance of Biodiesel as Transportation Fuel', Energy Policy 2007; 9: 4661-4670, DOI: 10.1016/j.enpol.2007.04.003

[4] C.Zamalloa, E.Vulsteke, J. Albrecht, and W.Verstraete. The techno-economic potential of renewable energy through the anaerobic digestion of microalgae. Bioresource Technology 2010; 102: 1149-1158, DOI: 10.1016/j.biortech,.09.017

[5] T.L.Walter, S. Purton, D.K. Becker, \& C. Collet. Microalgae as bioreactor. Plant Cell Rep. 2005; 24:62941, DOI:10.1007/s00299-005-0004-6

[6] P. T.Pienkos, and Al Darzins. The Promise and Challenges of Microalgal-derived Biofuels. Biofuels, Bioprod. Bioref 2009; 3: 431-40;DOI: 10.1002/bbb.159

[7] A.Saqib, M.R.Tabbssum, U.Rashid, M. Ibrahim, S.S Gill, and M. A.Mehmood. Marine macroalgae Ulva: potential feed-stock for bioethanol and biogas production. Asian J .Agri Biol, 2013; 1,155-163

[8] F.Ghasemi Naghdi, S. R.Thomas-Hall, R. Durairatnam, S. Pratt, P. M. Schenk. Comparative effects of biomass pretreatments for direct and indirect transesterification to enhance microalgal lipid recovery. Front. Energy Res. 2014; DOI:10.3389/fenrg.2014.00057

[9] A.P. Florentino de Souza Silva, M. Carantino Costa, A. Colzi Lopes, E. Fares Abdala Neto, R.Carrhá Leitão, C. Rossas Mota, and A. Bezerra dos Santos,. Comparison of pretreatment methods for total lipids extraction from mixed microalgae. Renewable Energy 2014, 63, 762-766; DOI: 10.1016/j.renene.2013.10.038

[10] D,Surendhiran, and M.Vijay. Effect of Various Pretreatment for Extracting Intracellular Lipid from Nannochloropsis oculata under Nitrogen Replete and Depleted Conditions. ISRN Chemical Engineering, 2014; DOI: $10.1155 / 2014 / 536310$

[11] S. K. Prajapati, A. Bhattacharya, A. Malik, and V.K. Vijay, "Pretreatment of algal biomass using fungal crude enzymes,” Algal Research 2015; 8: 8-14, DOI:10.1016/j.algal.2014.12.011

[12] K. Severson, M. Martín, I.E. Grossmann. Optimal biodiesel production using bioethanol: Towards process integration, 2012; DOI: 10.1002/aic.13865

[13] J.Fabregas, A.Maseda, A. Dominguez, and A. Otero. The cell composition of Nannochloropsis sp changes under different irradiances in semicontinuous culture. World J. Microbiol. Biotechnol , 2004; 20:31- 35

[14] M. Dubois, K.A. Gilles, J.K. Hamilton, P.A. Rebers and F. Smith. Colorimetric method for determination of sugars and related substances, 1956; Anal. Chem. 28:350-356

[15] G.L. Miller. Use of dinitrosalicylic acid reagent for determination of reducing sugar, 1959 Anal. Chem. 31:426- 428 . 